\title{
Studies on the Pollination Characteristics and Pollination Level of Chinese fir Seed Orchard
}

\author{
By Z. ZHuOweN
}

Dept. of Forestry, Huazhong Agricultural University, Wuhan 430070, China

(Received 24 th April 2003)

\begin{abstract}
Data from three seed orchards (Chongyang, Zhangle and Laoshan) and Lintian forest were used to study pollination characteristics, pollination level, pollen and ovule production in Chinese fir. The results show that male and female cones have their own distribution patterns within crowns. Male cones are located in the middle to top and female cones the middle to bottom part of the crown. Because of lower density of trees in seed orchard than that in a stand, female cones are distributed over the entire crown in seed orchard trees. Chinese fir male and female cones appear to be very well adapted for wind as the pollination mechanism. There is no difference in the number of pollen grains produced by one pollen sac among trees in the same clone, but there are differences between clones. There are differences between both clones and years in female cone number, male cone number and their ratio. The pollen accumulation rate during pollination should be 3 to 5 pollen grains $/ \mathrm{mm}^{2}$ to ensure fertilization. The Chinese fir seed orchards in this study produced too much pollen and could be improved by stimulation of more female flowers in order to produce more seeds.
\end{abstract}

Key words: Cunninghamia lanceolata (Lamb.) Hook, Chinese fir; seed orchard, clones, pollen, ovules.

In the area of tree breeding and improvement, Professor Cheng Yuewu was the person who established the first seed orchard of Chinese fir in China at Yangkou, Fujian Province (Yu Xintuo, 2000) in 1970s. There are 41 out of 288 families in this seed orchard that provide a 15 to $20 \%$ improvement over unimproved material. Professor SHI JISEN initiated a Chinese fir Breeding and Improvement Program, and set up the second generation seed orchard of Chinese fir at Sanming, Fujian Province (SHI JISEN, 1994). According to information from Chinese fir Superior Trees \& Seed Orchard Research Group, the wood volumes of 3 to 12 year-old trees from 337 clones are 37.8 to $81.6 \%$ greater than those of unimproved forests (SHEN XIHAN, 1990).

The purpose of setting up a seed orchard is to produce large amounts of high quality seeds. therefore increasing seed production is very important. Although there are many ways to do so, such as to increasing light intensity, fertilization, weed control and using flower stimulation techniques. An alternative method is to study the clonal flowering characteristics, which is the objective of this study.

\section{Materials and Methods}

Seed orchards and the Lintian forest used in this study

This research was carried out in three seed orchards (Chongyang, Zhangle and Laoshan) and the natural Lintian forest. The details of seed orchards and Lintian forest are shown in Table 1.

\section{Sampling Methods and Data Collection \\ Male and female cone distribution in crowns of Chinese fir}

Five trees of each clone selected at random in the seed orchard were selected for measurement. The crown was divided into upper, middle and lower regions by means of the branch number along the main trunk, selecting 4 average size branches in the east, west, north and south directions in each region of crown. After counting the female and male cones on these branches, the number of female and male cones of whole tree was estimated (ZHANG ZHUOWEN et al., 2001).

\section{Male and female cone adaptation to wind as a pollination mechanism}

During pollination some trees in seed orchard were selected and the following the characteristics of flowering of Chinese fir were observed (ZHANG ZHUOwEN et al., 2001).

\section{Pollen production per pollen sac and per tree}

Fifty microsporophylls were collected from sample male cones at random, put into $2 \mathrm{ml}$ liquid of glycerol and water (1:6), the pollen sacs were opened and pollen was washed out using a tweezer and an anatomical needle. Then pollen number is counted with a Neubauer haemacytometer under a microscope.

Twenty to 50 male cones were selected from a sample of cones of each clone at random. Each morphological item is measured 20 times. From this data the pollen number produced per tree is calculated (ZhANG ZHUOwen et al., 1990, 2001).

\section{Pollination level estimation}

Pollen collectors were set up in seed orchards and Lintian forest, using glass microscope slides coated with a thin layer of Vaseline and was changed every day at almost the same time (ZHANG ZHUOWEN et al., 1990, 2002 ). The accumulation rate of pollen during pollination and the maximum accumulation of

Table 1. - The details of seed orchards and the Lintian forest.

\begin{tabular}{|c|c|c|c|c|c|c|c|c|c|c|}
\hline Stand & Location & $\begin{array}{l}\text { Area } \\
\mathrm{m}^{2}\end{array}$ & $\begin{array}{c}\text { Spacing } \\
\mathrm{m}\end{array}$ & $\begin{array}{l}\text { Clone } \\
\text { number }\end{array}$ & $\begin{array}{c}\text { Age } \\
\text { (years) }\end{array}$ & $\begin{array}{c}\text { Height } \\
\mathrm{m}\end{array}$ & $\begin{array}{c}\mathrm{DBH} \\
\mathrm{cm}\end{array}$ & Latitude & Longitude & $\begin{array}{c}\text { Elevation } \\
\mathrm{m}\end{array}$ \\
\hline ChongyangS.O & Hillside & 80,000 & $5 \times 5$ & $\begin{array}{l}22 \\
32\end{array}$ & $\begin{array}{c}5 \text { to } 9 \\
7 \text { to } 11\end{array}$ & $\begin{array}{l}6.4 \\
7.4\end{array}$ & $\begin{array}{l}10.4 \\
12.8\end{array}$ & $29^{\circ} 38^{\prime} 27^{\prime \prime}$ & $114^{\circ} 8^{\prime} 19^{\prime \prime}$ & 148 to 226 \\
\hline Laoshan S.O & In Qiandaohu & 311,350 & $4 \times 4$ & 620 & 10 to 13 & 6.0 & 11.6 & $29^{\circ} 34^{\prime} 56^{\prime \prime}$ & $118^{\circ} 52^{\prime} 24^{\prime \prime}$ & 100 to 305 \\
\hline Zhangle S.O & Hillside & 342,838 & $5 \times 5$ & 657 & 10 to 14 & 6.7 & 12.0 & $30^{\circ} 16^{\prime} 32^{\prime \prime}$ & $120^{\circ} 12^{\prime} 28^{\prime \prime}$ & 64 to 150 \\
\hline Lintian forest & Hillside & 800,000 & $2.5 \times 2.5$ & 0 & 18 & 8.7 & 16.2 & $30^{\circ} 22^{\prime} 12^{\prime \prime}$ & $119^{\circ} 47^{\prime} 8^{\prime \prime}$ & 50 to 120 \\
\hline
\end{tabular}


Table 2. - Female and male cone distribution in the crown of Chinese fir.

\begin{tabular}{|c|c|c|c|c|c|c|c|c|}
\hline \multirow{2}{*}{ stand } & \multirow{2}{*}{$\begin{array}{l}\text { Crown } \\
\text { breadth } \\
\mathrm{m}\end{array}$} & \multirow{2}{*}{$\begin{array}{l}\text { Branches on } \\
\text { trunk }\end{array}$} & \multicolumn{3}{|c|}{ Male cones per tree } & \multicolumn{3}{|c|}{ Female cones per tree } \\
\hline & & & Top & middle & bottom & Top & middle & bottom \\
\hline Lintian forest & 2.4 & 38.4 & 10.2 & 230.1 & 242.9 & 301.1 & 71.0 & 1.3 \\
\hline Laoshan S.O & 3.2 & 74.7 & 103.1 & 419.5 & $1,136.9$ & 299.8 & 285.1 & 145.4 \\
\hline Zhangle S.O & 3.4 & 68.2 & 286.5 & 587.4 & $1,033.2$ & 242.2 & 189.3 & 54.9 \\
\hline ChongyangS.O (2001) & 2.3 & 43.0 & 13.6 & 85.4 & 170.2 & 120.7 & 170.7 & 150.6 \\
\hline ChongyangS.O (2003) & 3.1 & 52.0 & 39.4 & 136.5 & 269.7 & 109.1 & 142.6 & 112.8 \\
\hline
\end{tabular}

Note: this table is based on 20 clones for 2001, and 32 clones for 2003 of Chongyang seed orchard ${ }^{[4]}$

pollen per day for Chinese fir can be measured. From the data, the accumulation pollen indexes ( $\mathrm{Rm}$ and $\mathrm{Ra}$ ) can be calculated. $\mathrm{Ra}$ is the ratio of current accumulation rate of pollen in a seed orchard to the accumulation rate of pollen per area, $\mathrm{Rm}$ is the ratio of maximum accumulation pollen in a seed orchard to the maximum accumulation rate of pollen at pollination peak per day and per area. With Ra and Rm we are able to judge the pollination level in a seed orchard.

\section{Number of Ovules per tree}

Twenty to 50 female cones were selected from samples cones of each clone at random. Each morphological item was measured 20 times. The number of ovules produced per tree was then calculated (ZHANG ZHUOWEN, 2001, 1990).

\section{Pollen sedimentation velocity in still air}

A glass tube with diameter of $20 \mathrm{~cm}$ and length of $4 \mathrm{~m}$ is suspended and 100 grams pollen was shaken at the top of the tube. A stopwatch was used to record the time it takes pollen to travel from the top to the bottom of the tube, and this was repeated 5 times.

\section{Results and Discussion}

Female and male cones distribution in crowns of Chinese fir

The distribution of female and male cones in a tree crown shows that male cones are mainly in the middle to bottom region of the crown and female cones are mainly in the middle to top region of the crown. Because of the lower density of trees in seed orchard compared to a normal stand, the female cones are distributed throughout all regions of the tree crown in seed orchard. Trees in low density stands get more sunlight. The results are shown in Table 2.

Using the data from the Chongyang seed orchard the differences in female and male cones between clones can be seen. In the Chongyang seed orchard there are 445.8 male cones and 364.5 female cones per tree and the ratio of female cone to male cone is 0.9 . There are differences in the number of male cones per tree both between clones and between years. There is a difference in the number of female cones between clones, but not between years. There is also a difference in the ratio of female to male cones between years. See Table 3 and Table 4 .

\section{Pollination characteristics of Chinese fir}

Male and female cone adaptation for wind as a pollination mechanism

Pollen size is small and light in weight

Chinese fir pollen is almost like a ball with an equator axes length $39.9 \mu \mathrm{m}$, a pole axes length $37.4 \mu \mathrm{m}$, a volume of $30219 \mu^{3}$ and a weight of $1.98 \times 10^{-5} \mathrm{mg}$.

Pollen number is very large

A Chinese fir pollen sac produces 2,300 to 12,000 pollen grains, on average. A normal Chinese fir tree in a natural stand produces $7.83 \times 10^{9}$ pollen grains $\left(1.56 \times 10^{5} \mathrm{mg}\right)$ and 39,241 ovules. By contrast a tree in a seed orchard produces on average $2.19 \times 10^{10}$ pollen grains $\left(4.34 \times 10^{5} \mathrm{mg}\right)$ and 53,199 ovules.

The distribution of male and female cones is good for pollination

Female cones produced at the top of branches. This is good for cross pollination with little resistance of tree crown.

A special protein liquid ball is produced at the ovule aperture

The special protein liquid ball (pollen drop) at the ovule aperture is secreted by ovules. It is used to collect pollen, recognize pollen and nourish pollen during pollen germination.

Protection of pollen and ovule when raining

On the surface of a female and male cone there is a waxy covering, which can keep rain drops away.

Both the macrosporophyll and microsporophyll are able to open or close freely according to the weather.

Female cones and male cones mature at almost the same time

Although male cones are differentiated in May to June, and female cones from August to September, both female and male cones mature, pollinate and fertilize at almost the same time in March to April (Yu XINTUO, 1981).

\section{Chinese fir pollen sedimentation in still air}

In the condition of still air, when pollen sac open a pollen is effected by two forces, gravity and the resistance of air. We obtain:

$$
\mathrm{m} \times \mathrm{d} \mathrm{v} / \mathrm{dt}=\mathrm{mg}-\mathrm{kv}
$$

we finally get: $\mathrm{V}=\mathrm{mg} / \mathrm{k}$. The sedimentation velocity of a pollen in still air is related to pollen mass (or weight) and air resistance is measured at $\mathrm{V}=16.3 \mathrm{~cm} / \mathrm{s}, \mathrm{k}=1.22 \times 10^{-9} \mathrm{~g} . \mathrm{cm} / \mathrm{s}$.

\section{Estimation of Chinese fir pollination level}

Pollen production per a pollen sac and per tree

The pollen number per sac of a tree in Laoshan seed orchard, Zhangle seed orchard, Chongyang seed orchard and Lintian forest is $3,703,5,286,7,653$ and 4,365 grains respectively. There is no difference in pollen number per sac among trees in the same clone, but there are differences between clones, and this result is shown in Table 5 and Table 6.

\section{Chinese fir pollen production in a seed orchard}

Chinese fir pollen production in a seed orchard is determined by pollen number per pollen sac, the numbers of each different clones, the density and the total area (Table 7).

\section{Pollen sedimentation accumulation number during pollination}

Chinese fir pollination level is determined by not only pollination characteristics, tree number, tree age, density, but also 
Table 3. - Cone distribution in crowns in the Chinese fir seed orchard located at Chongyang.

\begin{tabular}{|c|c|c|c|c|c|c|c|c|c|c|c|c|}
\hline \multirow[t]{2}{*}{ Clone } & \multirow{2}{*}{$\begin{array}{c}\text { Tree } \\
\text { height } \\
\text { m }\end{array}$} & \multirow{2}{*}{$\begin{array}{c}\mathrm{DBH} \\
\mathrm{Cm}\end{array}$} & \multirow{2}{*}{$\begin{array}{l}\text { Branch } \\
\text { number } \\
\text { on Trunk }\end{array}$} & \multicolumn{3}{|c|}{ Male cones / branch } & \multirow{2}{*}{$\begin{array}{l}\text { Male } \\
\text { cones per } \\
\text { tree }\end{array}$} & \multicolumn{3}{|c|}{ female cones / branch } & \multirow{2}{*}{$\begin{array}{l}\text { Female } \\
\text { cones per } \\
\text { tree }\end{array}$} & \multirow{2}{*}{$\begin{array}{l}\text { Cone } \\
\text { Ratio } \\
\text { F:M } \\
\end{array}$} \\
\hline & & & & Top & mid & $\mathrm{mid}$ & & Top & mid & mid & & \\
\hline Xianning 7415 & 8.0 & 13.6 & 47.4 & 1.3 .0 & 6.8 & 29.6 & 595.7 & 7.6 & 12.86 & 11.7 & 507.5 & 0.9 \\
\hline Xianning 7405 & 7.6 & 14.8 & 50.6 & 2.0 & 7.0 & 18.8 & 468.9 & 5.2 & 5.8 & 1.2 & 205.1 & 0.4 \\
\hline Xianning 7416 & 7.4 & 11.2 & 49.0 & 2.8 & 9.2 & 19.0 & 506.3 & 15.2 & 16.4 & 19.2 & 829.7 & 1.6 \\
\hline Xianning 7431 & 7.4 & 12.4 & 69.6 & 1.4 & 4.8 & 10.0 & 375.8 & 11.2 & 13.8 & 14.2 & 909.4 & 2.4 \\
\hline Xianning 7430 & 8.8 & 12.8 & 48.2 & 0.2 & 1.8 & 6.8 & 140.7 & 5.6 & 7.0 & 16.8 & 472.4 & 3.4 \\
\hline Xianning 7408 & 8.6 & 15.6 & 72.4 & 4.0 & 11.2 & 26.8 & 1013.6 & 7.2 & 10.2 & 10.4 & 670.9 & 0.7 \\
\hline Xianning 7420 & 8.4 & 14.0 & 78.4 & 3.6 & 18.2 & 16.2 & 993.1 & 6.4 & 9.0 & 2.4 & 465.2 & 0.5 \\
\hline Xianning 7434 & 8.2 & 13.6 & 65.0 & 2.6 & 1.7 & 28.8 & 716.7 & 9.0 & 15.4 & 9.6 & 736.7 & 1.0 \\
\hline Xianning 7407 & 7.6 & 7.6 & 39.0 & 0.8 & 16.0 & 21.0 & 491.4 & 12.4 & 20.2 & 22 & 709.8 & 1.4 \\
\hline Xianning 7444 & 7.0 & 13.2 & 51.6 & 1.4 & 5.8 & 16.2 & 402.5 & 8.6 & 12.4 & 6.8 & 478.2 & 1.2 \\
\hline Fulinsuo7305 & 5.2 & 9.2 & 42.2 & 1.2 & 3.8 & 6.6 & 163.2 & 4.0 & 4.6 & 0.9 & 133.6 & 0.8 \\
\hline Fulinsuo 7316 & 6.2 & 13.6 & 42.8 & 1.4 & 6.0 & 10.4 & 253.9 & 5.0 & 8.6 & 3.8 & 248.2 & 1.0 \\
\hline Fulinsuo 6421 & 8.6 & 16.4 & 59.2 & 17.2 & 9.8 & 25.6 & 1038.0 & 2.4 & 10.6 & 5.2 & 359.1 & 0.3 \\
\hline Jinpinhui16 & 7.6 & 13.6 & 50.6 & 1.4 & 6.0 & 10.6 & 303.6 & 5.8 & 5.0 & 4.2 & 253.0 & 0.8 \\
\hline Xiang 03 & 7.6 & 14.0 & 48.1 & 6.4 & 10.6 & 9.6 & 426.5 & 12.2 & 14.4 & 8.0 & 554.8 & 1.3 \\
\hline Xiang 08 & 6.4 & 11.2 & 54.6 & 2.4 & 3.2 & 3.4 & 163.8 & 3.8 & 4.8 & 3.8 & 225.7 & 1.4 \\
\hline Yunyou 5 & 8.8 & 15.6 & 70.2 & 0.6 & 12.6 & 13.4 & 622.4 & 8.6 & 7.2 & 3.2 & 444.6 & 0.7 \\
\hline Fujian 431 & 6.4 & 12.0 & 50.4 & 3.6 & 13.6 & 29.6 & 786.2 & 4.8 & 7.8 & 9.4 & 369.6 & 0.5 \\
\hline Fujian 43 & 7.6 & 13.2 & 56.0 & 1.4 & 7.0 & 10.0 & 343.5 & 3.8 & 4.2 & 4.2 & 227.7 & 0.7 \\
\hline Fujian 20 & 7.0 & 12.4 & 40.4 & 0.4 & 3.0 & 16.6 & 269.3 & 5.0 & 9.6 & 2.6 & 231.6 & 0.9 \\
\hline Fujian 13 & 8.0 & 14.8 & 47.2 & 0.6 & 5.0 & 14.0 & 308.4 & 4.2 & 7.8 & 2.4 & 226.6 & 0.7 \\
\hline Fujian 35 & 7.0 & 12.8 & 40.4 & 1.6 & 13.4 & 18.0 & 444.4 & 5.8 & 8.4 & 3.6 & 239.7 & 0.5 \\
\hline Fujian 25 & 8.0 & 11.2 & 59.6 & 3.2 & 24.2 & 22.0 & 981.4 & 2.2 & 3.8 & 7.6 & 270.2 & 0.3 \\
\hline Fujian 4 & 7.2 & 14.8 & 45.0 & 2.8 & 7.2 & 19.0 & 435.0 & 8.4 & 8.6 & 4.6 & 324.0 & 0.7 \\
\hline Fujian 33 & 7.6 & 15.2 & 52.4 & 0.8 & 10.2 & 19.4 & 531.0 & 9.0 & 9.0 & 8.2 & 457.6 & 0.9 \\
\hline Fujian 2 & 7.6 & 11.6 & 32.0 & 0.0 & 5.2 & 13.2 & 196.3 & 7.6 & 7.8 & 10.6 & 277.3 & 1.4 \\
\hline Fujian 3 & 7.8 & 12.4 & 39.0 & 1.0 & 1.1 & 8.2 & 133.9 & 3.6 & 1.26 & 1.5 & 82.7 & 0.6 \\
\hline Fujian 9 & 6.2 & 12.0 & 34.4 & 1.4 & 1.36 & 6.8 & 109.6 & 3.0 & 3.6 & 2.4 & 103.2 & 0.9 \\
\hline Fujian 21 & 7.4 & 10.4 & 30.0 & 0.8 & 2.6 & 12.8 & 162.0 & 3.0 & 2.8 & 0.6 & 63.6 & 0.4 \\
\hline Fujian 27 & 7.2 & 12.8 & 37.4 & 0.8 & 9.6 & 9.8 & 251.8 & 7.2 & 5.0 & 1.1 & 165.8 & 0.7 \\
\hline Fujian 36 & 5.6 & 8.8 & 48.0 & 0.2 & 3.2 & 12.0 & 246.4 & 1.96 & 6.8 & 7.4 & 258.6 & 1.1 \\
\hline Fujian 39 & 6.2 & 12.0 & 42.4 & 3.2 & 10.6 & 13.6 & 387.3 & 4.8 & 4.4 & 2.2 & 161.1 & 0.4 \\
\hline average & 7.4 & 12.8 & 52.0 & 2.3 & 7.9 & 15.6 & $445.7^{*}$ & 6.4 & 8.4 & 6.6 & $364.5^{*}$ & 0.9 \\
\hline
\end{tabular}

* Note: two figures are not quite equal to sum of their cones of level of crown because of decimal point, these are errors of statistics.

Table 4. - Analysis of Variance for female and male cones both between clones and between years.

\begin{tabular}{ccccccccccc}
\hline $\begin{array}{c}\text { Variance } \\
\text { origin }\end{array}$ & df & \multicolumn{3}{c}{ Male cones } & \multicolumn{3}{c}{ Female cones } & \multicolumn{3}{c}{ Female cone:male cone Ratio } \\
\cline { 2 - 11 } & & SS & MS & F & SS & MS & F & SS & MS & F \\
\hline Clones & 19 & 1206641 & 63507.43 & $2.29^{*}$ & 2503155 & 131745 & $7.52^{* *}$ & 154.43 & 8.13 & 1.85 \\
Years & 1 & 587970.4 & 587970.4 & $21.18^{* *}$ & 2721.345 & 2721.345 & 0.16 & 23.61 & 23.61 & $5.38^{* *}$ \\
Error & 19 & 527497.2 & 27763.01 & & 333004.3 & 17526.54 & & 83.32 & 4.39 & \\
Total & 39 & 2322109 & & & 2838881 & & & 261.36 & & \\
\hline
\end{tabular}

$\mathrm{F}_{0.05}=2.16825, \mathrm{~F}_{0.01}=4.380752$ 
Table 5. - Pollen and ovule characteristics of Chinese fir trees among clones in seed orchard located at Chongyang.

\begin{tabular}{|c|c|c|c|c|c|c|c|c|c|}
\hline clone & Pollen a sac & $A$ & B & $\mathrm{C}$ & D & $\mathrm{E}$ & $\mathrm{F}$ & $\mathrm{G}$ & $\mathrm{H} \times 10^{5}$ \\
\hline Xianing 7420 & $11,353.1$ & 43.5 & 20.5 & 575.2 & $1.74 \times 10^{10}$ & 40.2 & 399.3 & $48,155.6$ & 3.62 \\
\hline Fujian 35 & $12,605.1$ & 40.8 & 24.4 & $269.1^{*}$ & $1.01 \times 10^{10}$ & 30.1 & $441.9^{*}$ & $39,907.2$ & 2.53 \\
\hline Fujian 27 & $5,432.5$ & 42.4 & 21.1 & $269.1^{*}$ & $3.92 \times 10^{9}$ & 36.9 & $441.9^{*}$ & $48,989.1$ & 8.00 \\
\hline Fujian 33 & $3,161.9$ & 44.0 & 28.2 & 202.7 & $2.38 \times 10^{9}$ & 38.1 & 210.9 & $24,108.2$ & 9.89 \\
\hline Fujian 13 & $2,695.0$ & 46.3 & 27.3 & 174.2 & $1.78 \times 10^{9}$ & 37.8 & 222.3 & $25,180.0$ & 7.07 \\
\hline Fulisuo 7316 & $2,355.5$ & 41.6 & 21.7 & 152.5 & $9.72 \times 10^{8}$ & 34.6 & 215.0 & $22,321.2$ & 4.35 \\
\hline Xianing 7405 & $3,034.6$ & 43.7 & 17.5 & 188.1 & $1.31 \times 10^{9}$ & 30.5 & 390.3 & $35,654.8$ & 3.66 \\
\hline Fujian 25 & $5,708.4$ & 38.9 & 14.4 & 148.2 & $1.42 \times 10^{9}$ & 35.4 & 117.3 & $12,454.1$ & 1.14 \\
\hline Xiang03 & $6,472.3$ & 40.1 & 24.1 & $269.1^{*}$ & $5.05 \times 10^{9}$ & 36.3 & $441.9^{*}$ & $48,127.3$ & 1.05 \\
\hline Fujian07 & $9,719.1$ & 39.2 & 19.3 & 92.5 & $2.03 \times 10^{9}$ & 40.7 & 54.1 & $6,603.2$ & 3.08 \\
\hline Xianing 7430 & $11,459.2$ & 53.3 & 14.8 & 56.7 & $1.54 \times 10^{9}$ & 33.6 & 685.2 & $68,968.4$ & 2.23 \\
\hline Xianing 7434 & $8,488.3$ & 41.9 & 18.7 & 521.0 & $1.04 \times 10^{10}$ & 32.1 & 379.3 & $36,464.9$ & 2.84 \\
\hline Fujian43 & $5,517.4$ & 44.3 & 24.2 & 378.5 & $6.71 \times 10^{9}$ & 43.0 & 271.2 & $34,983.5$ & 1.92 \\
\hline Yunyous & $14,493.7$ & 34.4 & 14.6 & $269.1^{*}$ & $5.86 \times 10^{9}$ & 30.6 & $441.9^{*}$ & $40,570.1$ & 1.45 \\
\hline Fujian442 & $12,965.8$ & 43.7 & 22.3 & $269.1^{*}$ & $1.02 \times 10^{10}$ & 31.4 & $441.9^{*}$ & $41,564.5$ & 2.46 \\
\hline Xianing 7416 & $10,122.3$ & 46.8 & 24.4 & 90.5 & $3.14 \times 10^{9}$ & 29.8 & 1149.3 & $102,575.9$ & 3.06 \\
\hline Jinpinghuil6 & $3,798.5$ & 44.8 & 19.6 & 205.7 & $2.06 \times 10^{9}$ & 29.4 & 386.0 & $33,987.3$ & 6.06 \\
\hline Xianing 7431 & $15,257.7$ & 53.0 & 22.0 & 326.8 & $1.74 \times 10^{10}$ & 34.3 & 1129.9 & $116,100.3$ & 1.50 \\
\hline Xiang 04 & $4,201.7$ & 42.4 & 19.5 & $269.1^{*}$ & $2.81 \times 10^{9}$ & 33.7 & $441.9^{*}$ & $44,680.1$ & 0.28 \\
\hline Xianing 7444 & $3,055.8$ & 43.8 & 20.4 & 393.8 & $3.23 \times 10^{9}$ & 36.9 & 628.1 & $69,432.0$ & 4.65 \\
\hline Fulisuo7305 & $4,880.8$ & 47.7 & 20.1 & 178.3 & $2.50 \times 10^{9}$ & 36.4 & 270.0 & $29,444.6$ & 8.50 \\
\hline Fujian 431 & $11,310.6$ & 44.7 & 25.3 & 351.3 & $1.35 \times 10^{10}$ & 37.6 & 533.7 & $60,196.9$ & 2.24 \\
\hline Fujian 6421 & $8,170.0$ & 51.8 & 19.7 & $269.1^{*}$ & $6.73 \times 10^{9}$ & 35.1 & $441.9^{*}$ & $46,483.3$ & 1.45 \\
\hline Fujian 04 & $6,684.5$ & 44.8 & 20.9 & 274.4 & $5.15 \times 10^{9}$ & 39.9 & 384.1 & $46,028.4$ & 1.12 \\
\hline Fujian 20 & $4,010.7$ & 40.8 & 19.2 & 269.1 & $2.54 \times 10^{9}$ & 33.7 & $441.9^{*}$ & $44,680.1$ & 5.68 \\
\hline Fujian7408 & $11,862.3$ & 44.4 & 17.7 & 333.1 & $9.28 \times 10^{9}$ & 32.9 & 461.6 & $45,555.0$ & 2.04 \\
\hline average & $7,653.3$ & 44.0 & 20.8 & $269.1^{*}$ & $5.66 \times 10^{9}$ & 35.1 & $441.9^{*}$ & $46,483.3$ & 1.22 \\
\hline
\end{tabular}

** Note: The basic number for female cone and male cone is $3 . \quad *$ Note: they are all averages in the table.

A the number of microsporophyll per microstrobilus $\quad B$ the number of microstrobili per male cone

$\mathrm{C}$ the number of male cones per tree

$\mathrm{B}$ the number of microstrobili per

$\mathrm{E}$ the number of macrosporophyll per female cone

$\mathrm{G}$ the number of ovules per tree

$\mathrm{F}$ the number of female cones per tree

$\mathrm{H}$ the ratio of pollen to ovule

pollen number per unit area and wind velocity. We can use the indexes of accumulation pollen rate during pollination per area or maximum pollen rate per day and per area at pollination peak to assess the pollination level. It was observed that the area of protein liquid ball (pollen drop) at ovule aperture is

Table 6. - Analysis of Variance for pollen number per sac both among trees in the same clone and between clones of Chinese fir in seed orchard located at Chongyang.

\begin{tabular}{cccccc}
\hline $\begin{array}{c}\text { Variance } \\
\text { origin }\end{array}$ & SS & df & MS & F & F crit \\
\hline $\begin{array}{c}\text { Between } \\
\text { clones }\end{array}$ & $110,555.2$ & 24 & $4,606.5$ & $6.1^{* * *}$ & 1.6 \\
$\begin{array}{c}\text { Among the } \\
\text { same clone }\end{array}$ & $4,151.0$ & 7 & 593.0 & 0.8 & 2.1 \\
$\begin{array}{c}\text { Error } \\
\text { Total }\end{array}$ & $\begin{array}{l}126,374.3 \\
241,080.6\end{array}$ & 168 & 752.2 & & \\
\hline
\end{tabular}

about 0.5 to $1.1 \mathrm{~mm}^{2}$. If there are 3 to 5 pollen grains at the ovule aperture, it is enough for fertilization. So a reasonable rate for accumulation pollen during pollination should be 4 pollen grains $/ \mathrm{mm}^{2}$, and the rate of maximum accumulation pollen at pollination peak should be 3 pollen grains/d.mm ${ }^{2}$. Therefore we can judge the pollination level of a Chinese fir seed orchard with these two indexes. As a results the pollination level of the three Chinese fir seed orchards in this study are too high. The $\mathrm{Ra}$ is 4 to 56 so in these seed orchards we need to stimulate more female cones in order to produce more seeds.

\section{Ovule number and the ratio of ovule to pollen}

The purpose of establishing a seed orchard is to produce seeds with high genetic quality. Seed production in a seed orchard is determined by the number of ovules, and seed quali- 
Table 7. - Pollen production of Chinese fir*.

\begin{tabular}{|c|c|c|c|c|c|c|}
\hline \multirow[t]{2}{*}{ Stand } & \multirow{2}{*}{$\begin{array}{c}\text { Pollen/ } \\
\text { sac }\end{array}$} & \multirow[t]{2}{*}{ Male-cones/ tree } & \multicolumn{2}{|c|}{ Pollen per tree } & \multicolumn{2}{|c|}{ All stand } \\
\hline & & & number & Weight (mg) & number & Weight (mg) \\
\hline Laoshan S.O & 3703.3 & 1659.5 & $3.51 \times 10^{10}$ & $6.97 \times 10^{5}$ & $6.55 \times 10^{14}$ & $1.30 \times 10^{10}$ \\
\hline Zhangle S.O & 5286.4 & 1907.2 & $3.74 \times 10^{10}$ & $7.43 \times 10^{5}$ & $5.13 \times 10^{14}$ & $1.02 \times 10^{10}$ \\
\hline \multirow[t]{2}{*}{ ChongyangS.O } & 7653.3 & $269.1(2001.3)$ & $5.66 \times 10^{9}$ & $1.12 \times 10^{5}$ & $1.81 \times 10^{13}$ & $3.59 \times 10^{8}$ \\
\hline & & $445.7(2003.3)$ & $9.37 \times 10^{9}$ & $1.86 \times 10^{5}$ & $3.00 \times 10^{13}$ & $5.95 \times 10^{8}$ \\
\hline Lintian forest & 4365.2 & 483.2 & $7.83 \times 10^{9}$ & $1.55 \times 10^{5}$ & $1.00 \times 10^{15}$ & $1.99 \times 10^{10}$ \\
\hline
\end{tabular}

* note: $656.07 \mathrm{mg} / \mathrm{cm}^{3}, 5.0396 \times 10^{4}$ grains per $\mathrm{mg}$

Table 8. - Accumulation pollen number during pollination (grain/ $/ \mathrm{mm}^{2}$ ).

\begin{tabular}{c|ccccc}
\hline \multirow{2}{*}{ Stand } & \multicolumn{3}{|c}{ Pollen grain $/ \mathrm{mm}^{2}$} & \multicolumn{2}{c}{$\mathrm{R}$} \\
\cline { 2 - 6 } & $\begin{array}{c}\text { Pollen accumulation } \\
\text { During pollination }\end{array}$ & Per day & $\begin{array}{c}\text { Max / Per day } \\
\text { (in peak pollination) }\end{array}$ & $\mathrm{Ra}$ & $\mathrm{Rm}$ \\
\hline Laoshan S.O & 223.33 & 6.98 & 53.50 & 55.83 & 17.83 \\
Zhangle S.O & 53.74 & 3.61 & 4.04 & 13.43 & 1.35 \\
ChongyangS.O & 16.28 & 1.33 & 10.77 & 4.07 & 3.59 \\
Lintian forest & 54.44 & 2.85 & 8.95 & 13.61 & 2.98 \\
\hline
\end{tabular}

Table 9. - Ovule production of Chinese fir*

\begin{tabular}{ccccc}
\hline Stand & $\begin{array}{c}\text { Number of female } \\
\text { Cones Per tree }\end{array}$ & $\begin{array}{c}\text { Number of } \\
\text { Ovules per tree }\end{array}$ & $\begin{array}{c}\text { Seed number } \\
\text { all stand }\end{array}$ & $\begin{array}{c}\text { Seed weight } \\
\text { all stand (kg)* }\end{array}$ \\
\hline Laoshan S.O & 730.4 & 76,821 & $1.49 \times 10^{9}$ & 10,968 \\
Zhangle S.O & 486.4 & 51,156 & $7.02 \times 10^{8}$ & 5,147 \\
ChongyangS.O & $441.9(2001)$ & 46,483 & $1.49 \times 10^{8}$ & 1,091 \\
& $364.5(2003)$ & 38,336 & $1.23 \times 10^{8}$ & 900 \\
Lintian forest & 373.1 & 39,240 & $5.02 \times 10^{9}$ & 36,854 \\
\hline
\end{tabular}

* note: 1 . The average WKS is 7.4 gram, and there are some of ovules fail to develop into good seeds.

2. we use the average macrosporophyll number (35.1) per female cone, which can produce ovules, to estimate the number of ovules of a tree and all stand.

ty is determined by many factors, one of which is the degree of the self fertilization. In general, the higher the self fertilization proportion in a seed orchard, the more the selfed seed the seed orchard will produce, but the lower the seed genetic quality. We should try to control or avoid self fertilization in a seed orchard.

The ratio of ovule to pollen is shown in Table 3 and Table 5. The ovule production in seed orchards or a stand is shown in Table 9. With the index of WKS (WKS is the air dried weight of 1000 mature seeds), we can forecast seed production for a seed orchard by means of ovules produced in this seed orchard discounting for failure of ovules during development.

\section{Conclusion}

From this study we can conclude that the male and the female cones have their own distribution regions in Chinese fir crown. The age, density of a stand, clone, climatic factors can effect male and female cones production, their ratio, and their distribution in crown. Both the Chinese fir male and female cones appear to be very well adapted for wind as the pollination mechanism in many ways. When a pollen leaves the pollen sac, it undergoes a slow, even sedimentation rate with the wind and topographical factors affecting this movement. With the methods used in this study we can obtain the important numbers of pollen and ovules produced in a seed orchard. We are able to judge the pollination level in a seed orchard by means of the pollen accumulation rate during pollination per area and the maximum accumulation pollen rate per day and per area at pollination peak.

\section{References}

YU XINTUO: A summary of the studies on Chinese fir in 1990's. Journal of Fujian College of Forestry 20 (1): 1-10 (2000). — SHI JISEN: The present situation of Chinese fir genetic improvement in Fujian province and the technical counter measures of developing it. Journal of Fujian Forestry Sci. \& Techn. 21 (3): 28-31 (1994). - SHEN XIHAN: Tree Breeding. Chinese Forestry Publish Co. Beijing 1990, page 100 (in Chinese). - Zhang Zhuowen et al.: Distribution of cones in the crown and the ratio of pollen to ovule in seed orchard of Cunninghamia lanceolata (Lamb.) Hook located at Chongyang. Journal of Huazhong Agricultural University 20 (2): 176-180 (2001). - ZHANG ZHUOWEN et al.: Cone characteristics of Chinese fir and pollen quantity of its seed orchard. Journal of Central-south forestry College 10 (2): 134-142 (1990). — ZHANG ZHUOWEN et al.: Study on ecological character of pollen in Chinese fir. SCIENTIA SILVAE SINICAE 26 (5): 410-418 (1990). — CHEN XIAOYANG et al.: Observations and Analyses of the pollen dispersal in the seed orchard of Cunninghamia lanceolata. Journal of Beijing Forestry University 13 (2): 48-53 (1991). — CHEN XIAOYANG et al.: Studies on Spacial distribution and the spread distance of pollen in Chinese fir seed orchards. Journal of Beijing Forestry University 18 (2): 24-30 (1996). ZHANG ZHUOWAEN: Pollen dispersal and its spatial distribution in seed orchards of Cunninghamia lanceolata (Lamb.) Hook. Silvae Genetica 51 (5-6): 237-241 (2002). - ZHANG ZHUOwen: Differences in Flowering Characteristic among Clones of Cunninghamia lanceolata (Lamb.) Hook. Silvae Genetica 51 (5-6): 206-210 (2002). - YU XINTUO: A observation on flower buds differentiation of Chinese fir. SCIENTIA SILVAE 15 (1): 46-49 (1981). 